\title{
Cultivation of Nannochloropsis sp. in Brackish Groundwater Supplemented With Municipal Wastewater as a Nutrient Source
}

\author{
Louise Lins de Sousa*, Dominique Silveira da Hora, Emerson Andrade Sales and Louisa \\ Wessels Perelo \\ Departamento de Engenharia Ambiental; Universidade Federal da Bahia; Salvador - BA - Brasil
}

\begin{abstract}
The aim of this work was to study growth potential of the green microalgae Nannochloropsis sp. using brackish groundwater from a well in the semi-arid northeast region of Brazil as culture medium. The medium was supplemented with (\%) 19.4, 22.0, 44.0 and 50.0\% of municipal wastewater after UASB treatment as a low-cost nutrient source. The results showed that the culture tested was capable of growing in the brackish groundwater even at salinity levels as low as 2 ppt. Furthermore it was shown that municipal wastewater could be used as a sole nutrient source for Nannochloropsis $s p$.
\end{abstract}

Key words: Microalgae, brackish groundwater, municipal wastewater, Nannochloropsis sp.

\section{INTRODUCTION}

The use of microalgae is very diverse and includes from environmental indicators to industrial use. Lipids obtained from microalgae have received growing attention during the last decade for the production of biofuels. Many species of microalgae can be induced to accumulate substantial amounts of lipids, leading to a high oil yield (Sheehan et al. 1998; Cheirsilp and Torpee 2012). The average lipid content varies between 20 and 50\% (Demírbas 2009; Kanda et al. 2012; Liam and Philip, 2012), but under certain conditions some species can reach $90 \%$ of dry weight (Illman et al. 2000; Chiu et al. 2009). Microalgae feed on inorganic nutrients and several species are capable of removing nitrogen and phosphorus from the effluents (Chisti 2007; PérezMartínez et al. 2010; Pittman et al. 2011). They are also capable of converting the nutrients to biomass at much higher rates than the conventional cultures of oleaginous plants. They do not occupy agricultural land for the cultivation, require only water and atmospheric $\mathrm{CO}_{2}$ associated with sunlight for growth (Mata et al. 2010; Huan et al. 2010).

The mass production of microalgae faces several challenges to become economically feasible, since the costs associated with the cultivation are still higher than the value of the final product, i.e. biodiesel (Schenk et al. 2008). One of the strategies to resolve this problem is the use of a low cost culture medium. Some species of microalgae are capable of growing in the water of low quality (saline or brackish), including municipal, industrial and agricultural wastewater, as well as removing nitrogen and phosphorus from these effluents (Pérez-Martínez et al. 2010; Pittman et al. 2011).

*Author for correspondence: linslouise@gmail.com 
The arid and semiarid regions of the world occupy around $40 \%$ of the earth's surface and due to increasing anthropogenic pressures, destruction of native vegetation, soil degradation, accelerated processes of desertification and global climate change, the proportions of these areas have increased substantially in recent decades (Barbosa 2006). The Brazilian northeastern semi-arid region represents approximately $18.2 \%$ of the nations territory and $70.6 \%$ of the Northeast region. Large areas of this region exhibit favorable conditions for microalgae cultivation, because the temperature presents little variation, insolation is high and large quantities of groundwater are saline, or brackish, and therefore unfit for human consumption and irrigation, making these areas unsuitable for agriculture. At the same time, it is a semi-arid region with a relatively high population density compared to other semi-arid regions in the world with over 20 million people, representing more than $10 \%$ of Brazil's population. In this context, the semi-arid region of the Brazilian Northeast becomes an interesting region for the cultivation of microalgae on a large scale, offering space, sunlight, as well as low cost cultivation medium (brackish, or saline groundwater) and nutrient sources (municipal wastewater).

This study aimed to evaluate the growth potential of the green microalgae Nannochloropsis $s p$. in culture medium using brackish groundwater from the Brazilian semi-arid region and municipal wastewater as a nutrient source.

\section{MATERIALS AND METHODS}

\section{Microalgae, medium composition and preparation of culture media}

The species selected for cultivation was a strain of Nannochloropsis sp. obtained from the governmental aquiculture project Bahia Pesca and maintained in the algae collection of the Laboratory for Bioenergy and Catalysis (LABEC), located at the Polytechnical School, Federal University of Bahia (EP UFBA). The microalgal species was chosen due to its high content of triglycerides, as reported in literature (Chisti 2007; Moazami et al. 2012; Talukder et al. 2012) and based on previous studies evaluating the growth of several species present in the algae collection in culture medium with saline water indicating the best results for Nannochloropsis sp. The wastewater used as a nutrient source was collected at the treatment station in Praia do Forte $\left(12^{\circ}\right.$ $39^{\prime} \mathrm{S}, 38^{\circ} 5^{\prime} \mathrm{W}$ ), Bahia, $80 \mathrm{~km}$ north of Salvador. The wastewater was removed after the anaerobic treatment in an UASB reactor and analyzed at the Laboratory for Residues and Effluents (LABRE), also situated at EP UFBA. The brackish water used for the preparation of culture media was collected from a well in the region of Ipirá $\left(12^{\circ}\right.$ $\left.09^{\prime} \mathrm{S} 39^{\circ} 44^{\prime} \mathrm{W}\right)$, Bahia, Brazil and analyzed at the Laboratory of the Department of Environmental Engineering (LABDEA), EP UFBA, following the procedures described in the Standard Methods for the Examination of Water and Wastewater (Apha 2005).

\section{Medium composition}

Nutrient addition to the culture media was based on the modified Conway Medium (Walne, 1979) consisting of the nutrients (mg. $\left.\mathrm{L}^{-1}\right)$ : $\mathrm{Na}_{2}$ EDTA, 45 ; $\mathrm{NaNO}_{3}, \quad 100 ; \quad \mathrm{H}_{3} \mathrm{BO}_{3}, \quad 33.6 ; \quad \mathrm{Na}_{2} \mathrm{HPO}_{4}, \quad$ 20; $\mathrm{MnCl}_{2} .4 \mathrm{H}_{2} \mathrm{O}, 0.36 ; \mathrm{FeCl}_{3} .6 \mathrm{H}_{2} \mathrm{O}, 1.3,1 \mathrm{~mL} \mathrm{~L}^{-1}$ of trace metal solution $\left(\mathrm{ZnCl}_{2}, 2,1\right.$ g. $\mathrm{L}^{-1} ; \mathrm{CoCl}_{2} \cdot 6 \mathrm{H}_{2} \mathrm{O}$, 2 g.L $\mathrm{L}^{-1} ; \quad\left(\mathrm{NH}_{4}\right) 6 \mathrm{Mo}_{7} \mathrm{O}_{24} \cdot 4 \mathrm{H}_{2} \mathrm{O}, \quad 0,9 \quad$ g.L $\mathrm{L}^{-1}$; $\mathrm{CuSO}_{4} .5 \mathrm{H}_{2} \mathrm{O}, 2$ g. $\left.\mathrm{L}^{-1}\right)$ and vitamin solution 1 mL. $\mathrm{L}^{-1}$ (Tiamina, 100 mg. $\mathrm{L}^{-1}$; Cianocobalamina, 2 mg. $L^{-1}$; Biotina, $1 \mathrm{mg} . \mathrm{L}^{-1}$ ). Growth media with Conway nutrients were prepared using either diluted seawater $(80 \%$ seawater, $20 \%$ distilled water) (C- controls), or brackish groundwater (SG). Growth media receiving municipal wastewater as a nutrient source (SGMW) were prepared with brackish groundwater and varying volumes of wastewater (expressed in \% of the total volume of the culture medium): $\mathrm{V}_{1}=19 \%, \mathrm{~V}_{2}=$ $22 \%, \mathrm{~V}_{3}=44 \%$ and $\mathrm{V}_{4}=50 \%$. Sterilization by autoclaving during $15 \mathrm{~min}$ was performed only for the controls in the first experiment. All other culture media were inoculated without sterilization.

\section{Experiments}

In a first step, the overall ability of Nannochloropsis sp. to grow in brackish groundwater and to use the municipal wastewater as a nutrient source was evaluated. Culture media C, SG and SGMW were prepared in duplicates. Then evaluated the growth of Nannochloropsis sp in SG (controls) and SGMW medium with four different wastewater concentrations: $\mathrm{V}_{1}=19 \%, \mathrm{~V}_{2}$ $=22 \%, \mathrm{~V}_{3}=44 \%$ and $\mathrm{V}_{4}=50 \%$. The cultivation tests were performed by adding $10 \mathrm{~mL}$ of inoculum to $150 \mathrm{~mL}$ of culture medium in aerated Erlenmeyer flasks of $250 \mathrm{~mL}$, which were 
maintained at $22{ }^{\circ} \mathrm{C}$ and a light intensity of approximately $60 \mu \mathrm{mol}$ photons $\mathrm{m}^{-2} \mathrm{~s}^{-1}$. The monitoring of the cultures was performed by cell counting in a Neubauer counting chamber (Boeco Germany) using an optical microscope (Axiostar plus, Carl Zeiss) during 14 to 16 days. When the cultures reached the stationary phase, biomass production was evaluated by the determination of dry weight gravimetrically as follows: fiberglass filter paper $(45 \mu \mathrm{m}$, Macherey-Nagel) was dried until weight remained constant. Then $30 \mathrm{~mL}$ of each culture was filtered and filters were placed to dry at $70^{\circ} \mathrm{C}$ for $24 \mathrm{~h}$. Filters were weighed and the dry biomass was determined by the difference between the initial and final filter weight.

\section{RESULTS AND DISCUSSION}

\section{Groundwater and wastewater analysis}

Table 1 shows some characteristics of the brackish groundwater compared to seawater, used for the preparation of culture media for Nannochloropsis sp.

Table 1 - Chemical composition of groundwater from the well in Ipirá, Bahia, Brazil and sea water from Ondina Beach, Salvador, Bahia, Brazil sampled December $7^{\text {th }} 2010$.

\begin{tabular}{|c|c|c|c|}
\hline Parameter $\left(\mathrm{mg} \mathrm{L}^{-1}\right)$ & Brackish groundwater (well) & Sea water & Methods \\
\hline Chloride & 2170 & 21072 & SM 4500-Cl B 21 ${ }^{\mathrm{a}} \mathrm{Ed}$ \\
\hline Salinity $*$ & 3920 & 38068 & - \\
\hline Phosphate & 0.11 & $<0.01$ & SM 4500-CP D $21^{\mathrm{a}} \mathrm{Ed}$ \\
\hline Nitrate & 8.73 & 0.03 & SM 4500-NO3 E $21^{\mathrm{a}} \mathrm{Ed}$ \\
\hline Total Nitrogen & 8.30 & 0.80 & HACH 10071 ou 10072 (LR e HR) \\
\hline Suspended solids & $<10$ & 16.60 & SM $2540 \mathrm{D} 21^{\mathrm{a}} \mathrm{Ed}$ \\
\hline
\end{tabular}

* calculated by the JPOTS formula (UNESCO, 1966): $\mathrm{S}(\% \circ)=1,80655 \mathrm{Cl}(\% \circ)$

The wastewater used in the experiments was removed after the anaerobic treatment in an UASB reactor at the treatment station in Praia do Forte, Bahia, Brazil and was analyzed. The results are shown in Table 2.

Table 2 - Characterization of the municipal wastewater after UASB reactor at the treatment station Praia do Forte, Bahia, Brazil.

\begin{tabular}{ll}
\hline Parameter & Concentration \\
\hline Ammonia & $39,20 \mathrm{mg} \mathrm{NH}_{3}-\mathrm{N} \mathrm{L}^{-1}$ \\
TKN* & $54,88 \mathrm{mg} \mathrm{TKN} \mathrm{L}^{-1}$ \\
soluble P & $4,97{\mathrm{mg}\left(\mathrm{PO}_{4}\right)^{3-}-\mathrm{P} \mathrm{L}^{-1}}_{\text {pH }}^{7,18}$ \\
Alkalinity & $345 \mathrm{mg} \mathrm{CaCO}_{3} \mathrm{~L}^{-1}$ \\
\hline *TKN = Total Kjeldahl Nitrogen
\end{tabular}

\section{Cell growth monitoring}

The first test was carried out in order to evaluate whether the selected Nannochloropsis sp. could grow in the medium with brackish water and would be able to utilize nutrients from municipal wastewater. Figure 1 shows that the growth curves were similar in all the three culture media. Cultures in Conway medium prepared with brackish groundwater (SG) and those in brackish groundwater with addition of $\mathrm{V}=19 \%$ municipal wastewater (SGMW) did not differ considerably from the control cultures. Therefore, it could be concluded that it was possible to use the brackish groundwater with municipal wastewater as a nutrient source as culture medium of for the strain of Nannochloropsis sp. No contamination by other microorganisms was observed in the SGMW cultures, which was in accordance with Macalta (2011) who considered marine microalgae as more suitable for large scale production, because the salinity of the medium avoided contamination.

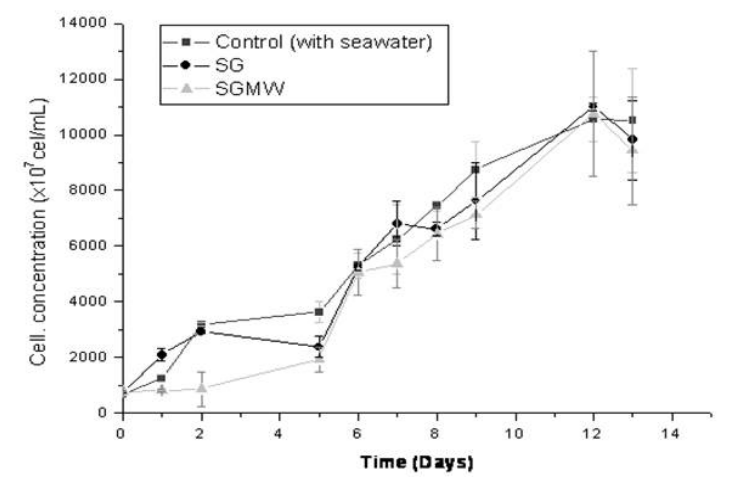

Figure 1 - Growth curve of Nannochloropsis sp. (control - cultivation in modified Conway medium prepared with diluted sea water; SG - cultivation in modified Conway prepared with brackish groundwater; SGMW - cultivation in brackish groundwater with addition of wastewater as a nutrient source). 
The amount of dry biomass obtained from each culture medium at the end of the experiment is shown in Table 3. Final biomass concentrations obtained in three culture media were quite similar, not showing a considerable difference between them Comparing with the results obtained by Gris (2011), who obtained a maximum biomass concentration of $0.2182 \mathrm{~g} . \mathrm{L}^{-1}$ (under culture conditions of $45 \mathrm{mg} . \mathrm{L}^{-1}$ of $\mathrm{NaNO}_{3}, 68 \mu \mathrm{mol}$ photons. $\mathrm{m}^{-2} \cdot \mathrm{s}^{-1}$ and $\mathrm{T}=24^{\circ} \mathrm{C}$ ), the biomass concentration obtained in this study was higher, with 0.9 g.L $\mathrm{L}^{-1}$ (using wastewater as a nutrient source, light intensity of $60 \mu \mathrm{mol}$ photons. $\mathrm{m}^{-2} . \mathrm{s}^{-1}$ and $\mathrm{T}=22^{\circ} \mathrm{C}$ ). These results confirmed that the selected species was able to grow in the culture medium with wastewater.

In the following experiments, the wastewater addition was increased randomLy in order to
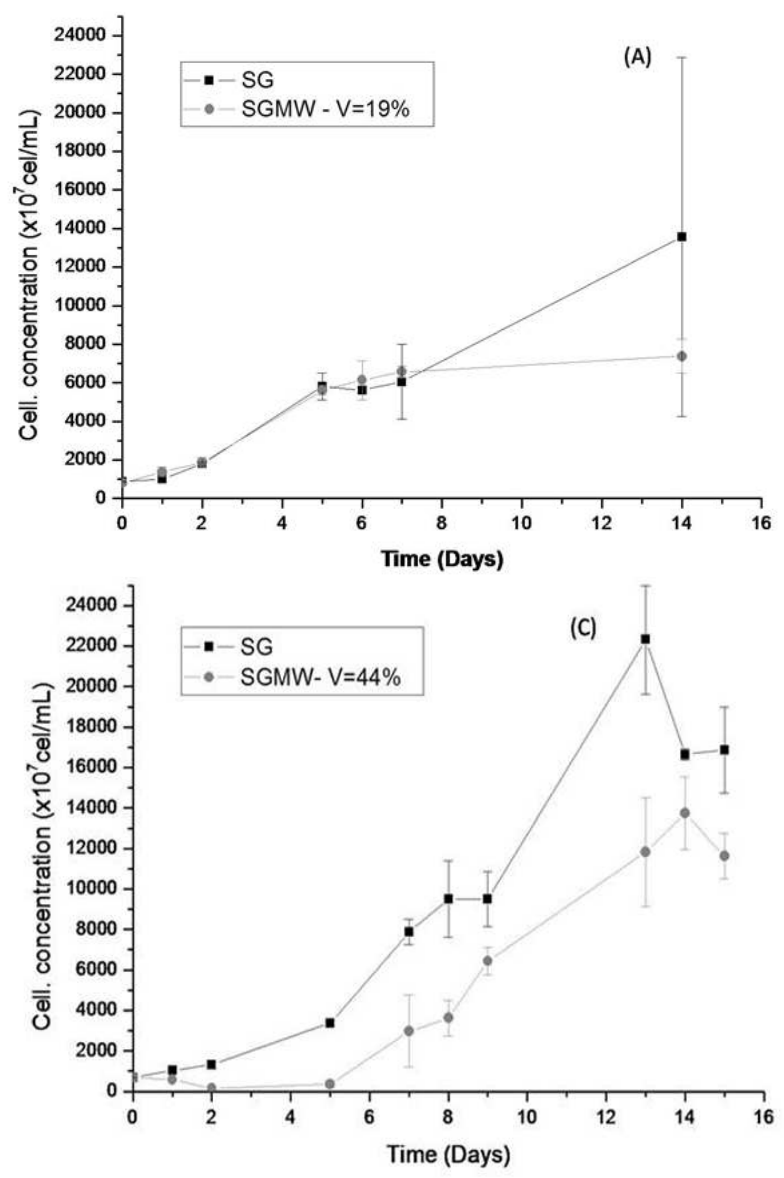

evaluate if the biomass concentration could be enhanced for higher nutrient availability. Figure 2 shows the cell concentrations $\left(\times 10^{7}\right.$ cel. $\left.\mathrm{mL}^{-1}\right)$ obtained for each variation of wastewater volume added. It could be observed that the cell density of the control (Conway medium with bracksih groundwater) was higher than the cell concentrations in the experiments with wastewater addition.

Table 3 - Quantification of cell concentration and dry biomass in the first experiment $(\mathrm{C}-$ Conway medium with sea water; SG - Conway medium with saline groundwater; SGMW - saline groundwater with $19 \%$ wastewater addition).

\begin{tabular}{ccc}
\hline Experiment & $\begin{array}{c}\text { Cell concentration } \\
\left(\mathbf{x 1 0} \text { cel.mL }^{-1}\right)\end{array}$ & $\begin{array}{c}\text { Dry biomass } \\
\left(\mathbf{g . L}^{-1}\right)\end{array}$ \\
\hline C & 10,5 & 1,86 \\
SG & 9,8 & 1,1 \\
SGMW & 9,4 & 0,9 \\
\hline
\end{tabular}
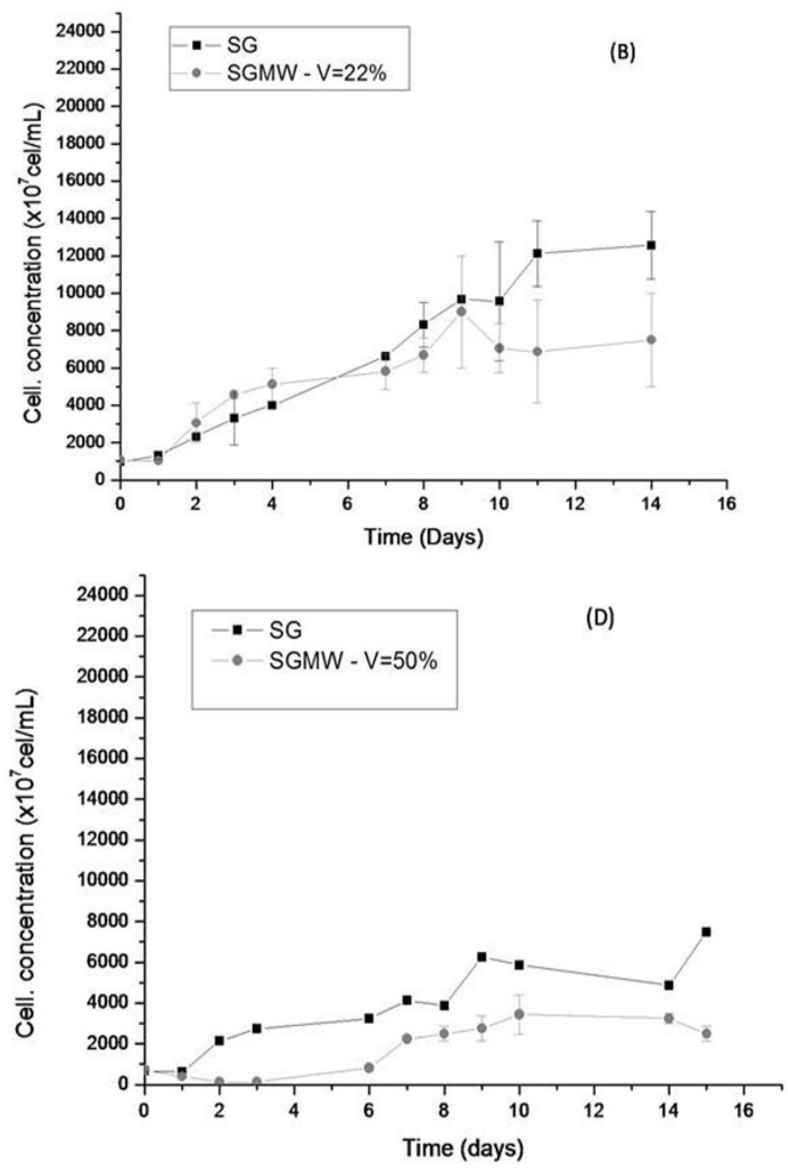

Figure 2 - Growth curves showing the evolution of cell density $\left(10^{7}\right.$ cel. $\left.\mathrm{L}^{-1}\right)$ of Nannochloropsis $\mathrm{sp}$. in controls (SG - Conway medium with brackish groundwater) and with four different volumes of wastewater added (SGMW): (A) 19.4\%, (B) 22\%, (C) 44\%, (D) $50 \%$. 
It could also be observed that increasing wastewater addition from 19 to $22 \%$ did not increase cell concentration considerably (Table 4), which might have been due to the relatively small increase of $3 \%$. But with the addition of $44 \%$, cell growth was almost two times as high as compared to the addition of 19 and $22 \%$ the wastewater. At a volume of $50 \%$, a reduction in cellular growth was observed both in the control and wastewater cultures. As the reduction also occurred in controls, it could not be attributed to excess of wastewater addition. Comparing the results of dry biomass achieved with each volume of wastewater added to the values of the respective controls (Table 4), it was seen that the addition of $19.4 \%$ and $22 \%$ of wastewater did not lead to a reduction of biomass production, while the higher additions (40 and 50\%) led to $20-30 \%$ reduction in comparison to the controls. Reduction at higher volumes of wastewater could be attributed to some kind of inhibitory substance present in the wastewater, or to the decrease in the salinity due to the higher volume of the wastewater added.

While highest cell concentrations were obtained for a wastewater volume of $44 \%$, biomass concentration did not vary much between the volumes of 19 nto $44 \%$, being highest at $44 \%$. This result confirmed that the biomass production was not directly related to cell number, since this also depended on the cell size. Cell growth and biomass concentration were comparable in the first (Table 3) and in the second experiment (Table 4). Compared to cell density values published for Nannochloropsis in the literature, reaching up to $52.9 \times 10^{7}$ cel. $\mathrm{mL}^{-1}$ in an outdoor experiment $(588 \mathrm{~L}$ coiled tube reactor, $23-31^{\circ} \mathrm{C}, 530 \mu \mathrm{mol}$ photons $\mathrm{m}^{-2} \mathrm{~s}^{-1}$ ) (Briassoulis et al. 2010), the values determined in this study (batch culture, $22^{\circ} \mathrm{C}, 60$ umol photons $\mathrm{m}^{-2} \mathrm{~s}^{-1}$, aeration) were relatively low. The main factor responsible for this difference might be the different light intensities, which direct influenced the photosynthesis, and therefore the growth. Higher temperatures may accelerate the organism's metabolism, enhancing growth as well. Another possible factor for low cell density is the $\mathrm{pH}$, which determines the availability of $\mathrm{CO}_{2}$ and $\mathrm{HCO}^{3-}$ for algal photosynthesis. As $\mathrm{pH}$ was not controlled, $\mathrm{pH}$ values varied between 9.0 and 10.0 after the first culture days, which ensured that at least $68 \%$ of the dissolved inorganic carbon (DIC) was present in a form that could be utilized by the algae (Knud-Hansen 2006).

Table 4 - Quantification of cell concentration and dry biomass in the second experiment (Control (SG) - Conway medium in brackish groundwater; SGMW - Brackish groundwater with addition of different volumes of municipal wastewater: $19.4 \%, 22 \%, 44 \%$ and $50 \%)$.

\begin{tabular}{|c|c|c|c|c|}
\hline & \multicolumn{2}{|c|}{ CONTROL $($ SG) } & \multicolumn{2}{|c|}{ SGMW } \\
\hline $\begin{array}{l}\text { Wastewater } \\
\text { volume }(\%)\end{array}$ & $\begin{array}{l}\text { Cell concentration } \\
\left(\times 10^{7} \text { cel.mL }^{-1}\right)\end{array}$ & $\begin{array}{c}\text { Dry biomass } \\
\left(\text { g. }^{-1}\right)\end{array}$ & $\begin{array}{l}\text { Cell concentration } \\
\left(\times 10^{7} \text { cel.mL }^{-1}\right)\end{array}$ & Dry biomass $\left(\right.$ g.L $\left.\mathrm{L}^{-1}\right)$ \\
\hline 19.4 & 13.5 & 0.84 & 7.4 & 0.85 \\
\hline 22 & 12.5 & 0.95 & 7.5 & 0.97 \\
\hline 44 & 16.6 & 1.20 & 13.8 & 0.96 \\
\hline 50 & 7.5 & 0.53 & 2.5 & 0.39 \\
\hline
\end{tabular}

Another phenomenon observed during the experiments with higher volumes of wastewater was that the test cultures had a yellowish color compared to the controls during all days of culture, indicating that the cells of Nannochloropsis sp. changed to a stress condition. This stress could be due to the absence of a nutrient, or the decreasing salinity as a consequence of wastewater addition to the brackish groundwater. Pigment production by $N$. gaditana as a response to nutrient deficiency (P, $\mathrm{N}, \mathrm{S})$, or salinity (15 to $100 \mathrm{ppt}$ ) were investigated by Froján et al. (2007) and Lubián (2000), respectively. Nutrient limitation, especially $S$ limitation, increased the production of carotenoids, while no clear effect of salinity on the pigment contents was found. The influence of salinity on biomass and lipid production by Nannochloropsis sp. has been investigated, concentrating on the influence of hypersalinity stress on the growth performance of these microalgae (Renaud and Parry 1994; Pal et al. 2011; Gu et al. 2012). Salinity ranges investigated ranged from 10 to $55 \%$, with no significant differences in the growth rate and biomass production found in the range of 10 to $35 \%$, decreasing with salinity above this level. No references could be found reporting growth behavior of Nannochloropsis at salinity levels lower to $10 \%$ o. The results obtained in the 
present work showed that the strain of Nannochloropsis sp. tested was able to grow at a salinity as low as $2 \%$ ( $50 \%$ wastewater addition).

The brackish groundwater used in the present study originated from a well in the semiarid northeast region of Brazil. This region has a high potential for microalgae biomass production due to low variation in temperature range, high solar radiation, presence of high amounts of brackish and saline ground water inappropriate for consumption or irrigation, as well as the presence of large areas unsuitable for agricultural use (Pereira et al. 2011). Furthermore, the Brazilian semiarid region, unlike many other semiarid regions of the world, is densely populated, with over 20 million inhabitants, representing more than $10 \%$ of the total population of the country (Cirilo et al. 2008), which implies a corresponding water consumption and wastewater production. The cultivation of microalgae species that tolerate brackish groundwater as a growth medium and are able to use domestic wastewater as a nutrient source, such as the strain of Nannochloropsis tested in the present work, could present a sustainable economic alternative for the local population as well as contributing to wastewater treatment and deposition in this region.

\section{CONCLUSION}

The possibilities of the economical use of microalgal biomass are well known. Species of the genus Nannochloropsis have been evaluated worldwide for biomass production, as they are able to produce high amounts of lipids, which can be used for biodiesel production. Besides this, these organisms can produce pigments as carotenoids under certain conditions. The strain of Nannochloropsis sp. tested was able to grow in brackish groundwater from a well in semi-arid arid northeastern region of Brazil with domestic wastewater as the only source of nutrients. The species was able to grow in low salinities, as groundwater had a salinity ten times lower than that of seawater. Both of these resources, brackish groundwater and domestic wastewater are widely available in the Brazilian Semi-Arid Northeast, a region with a low economic development. The cultivation of microalgal species such as the strain of Nannochloropsis tested has the potential to turn itself into a sustainable economic alternative for this region and may contribute to wastewater treatment and deposition.

\section{ACKNOWLEDGEMENTS}

This work has been supported by the Research Support Foundation of the State of Bahia (FAPESB) and the National Council for Scientific and Technological Development (CNPq).

\section{REFERENCES}

Apha. Standard methods for the examination of water and wastewater, 21st Ed, Ed.: Eaton AD, Clesceri LS, Rice EW and Greenberg AE. American Public Health Association, 2005.

Barbosa JEL. Dinâmica do fitoplânction e condionantes limnológicos nas escalas de tempo (nictemeral/sazonal) e de espaço (horizontal/vertical) no açude Traperoá II: trópico semi-árido nordestino [Tese de Doutorado]. São Carlos: Universidade Federal de São Carlos, 2006.

Briassoulis D, Panagakis P, Chionidis M, Tzenos D, Lalos A, Tsinos C, Berberidis K, Jacobsen A. An experimental helical-tubular photobioreactor for continuous production of Nannochloropsis sp. Bioresour Technol. 2010; 101 (17): 6768-6777.

Cheirsilp B, Torpee S. Enhanced growth and lipid production of microalgae under mixotrophic culture condition: Effect of light intensity, glucose concentration and fed-batch cultivation. Bioresour Technol. 2012; 110: 510-516.

Chisti Y. Research review paper: Biodiesel from Microalgae. Biotech Adv. 2007; 25: 294-306.

Chiu SY, Kao CY, Tsai MT, Ong SC, Chen CH, Lin CS. Lipid accumulation and $\mathrm{CO}_{2}$ utilization of Nannochloropsis. oculata in response to $\mathrm{CO} 2$ aeration. Bioresour Technol. 2009; 100:833-838.

Cirilo, J. A. Politicas públicas de recursos hídricos para o semiárido. Scielo - Estudos Avançados. 2008; 22 (63): 61-82.

Demírbas_ A. Production of biodiesel from algae oils. Energy Source A, 2009;31:163-168.

Gris LRS. Produção da microalga Nannochloropsis oculata em fotobiorreator airlift [Dissertation]. Porto Alegre, Rio Grande do Sul: Federal Universidade do Rio Grande do Sul; 2011.

Gu N, Lins Q, Qin G, Lin J, Huang L. Effect of salinity change on biomass and biochemical composition of Nannochloropsis oculata. J World Aquacult Soc. 2012; 43 (1): 97-106.

Huan G, Chen F, Wei D, Zhang X, Chen G. Biodiesel production by microalgal biotechnology. Appl Energy. 2010; 87: 38-46. 
Illman AM, Scragg AH, Shales SW. Increase in chlorella strains calorific values when grown in low nitrogen medium. Enzyme Microb Technol. 2000; 27: 631-635.

Kanda H, Li P, Ikehara T, Yasumoto-Hirose M. Lipids extracted from several species of natural blue-green micoalgae by dimethyl ether; Extraction yield and properties. J Fuel. 2012; 95: 88-92.

Knud-Hansen CF. Pond Fertilization: Ecological approach and practical application. 2nd ed. Oregon: Oregon State University; 2006.

Liam B, Philip O. Biofuels from microalgae - a review of technologies for production processing, and extraction of biofuels and co-products. Renew Sustain Energ Rev. 2010; 14:557-77.

Macalta FX. Microalgae and biofuels: A promising partnership?. TIB. 2011; 29 (11): 542-549.

Mata TM, Martins AA, Caetano NS. Microalgae for biodiesel production and other applications: A review. Renew Sustain Energ Rev. 2010; 14 (1): 217232.

Moazami N, Ashori A, Ranjbar R, Tangestani M, Eghtesadi R, Nejad AS. Large-scale biodiesel production using microalgae biomass of Nannochloropsis sp. Biomass and Bioenergy. 2012; 39: 449-453.

Pal D, Khozin-Goldberg I, Cohin Z, Boussiba S. The effect of light, salinity and nitrogen availability on lipid production by Nannochloropsis sp. Appl Microbiol Biotechnol. 2011; 90: 1429-1441.

Pereira DA, Kiperstok AC, Sales EA, Cortes OJ, Perelo LW. Microalgae growth potential in brazilian semiarid region. In: 19th European Biomass Conference and Exhibition; 2011; Berlim, Alemanha.
Pérez-Martínez C, Sánchez-Castillo P, Jiménez-Pérez MV. Utilization of immobilized benthic algal species for N and P removal. J Appl Phycol. 2010; 22: 277282.

Pittman JK, Dean AP, Osundeko O. The potential of sustainable algal biofuel production using wastewater resources. Bioresource Technol. 2011; 102; 17-25.

Renaud SM, Parry DL. Microalgae for use in tropical aquaculture II: Effect of salinity on growth, gross chemical composition and fatty acid composition of three species of marine microalgae. J Appl Psychol. 1994; 6: 347-356.

Schenk PM, Thomas-Hall SR, Stephens E, Marx UC, Mussgnug JH, Posten C, Kruse O, Hankamer B. Second generation biofuels: high-efficiency microalgae for biodiesel production. Bioenerg Res. 2008; 1: 20-43.

Sheehan J, Dunahay T, Benemann J, Roessler P. A look back at the U.S. Department of Energy's aquatic species program: biodiesel from algae. National Renewable Energy Laboratory. USA, 1998.

Talukder MMR, Das P, Chuan Wu J. Microalgae (Nannochloropsis salina) biomass to lactic and lipid. Biochem Eng J. 2012; 68: 109-113.

Walne PR. Culture of Bivalve Molluscs: 50 years experience at Conwy. 2th Edition. Londres: The Whitefriars Press Ltd; 1979.

Received: February 15, 2013; Accepted: November 04, 2013. 